\title{
Multiple Calcium-Activated Neutral Proteinases (CANP) in Mouse Retinal Ganglion Cell Neurons: Specificities for Endogenous Neuronal Substrates and Comparison to Purified Brain CANP
}

\author{
Ralph A. Nixon, Rebecca Quackenbush, and Anthony Vitto \\ Ralph Lowell Laboratories, Mailman Research Center, McLean Hospital, Belmont, Massachusetts 02178, and \\ Department of Psychiatry and Program in Neuroscience, Harvard Medical School, Boston, Massachusetts 02115
}

Calcium-activated neutral proteinases (CANPs) and their specificities for axonally transported proteins were studied within intact axons of mouse retinal ganglion cell (RGC) neurons in vitro. Two CANP activities with markedly different properties were identified. CANP B, at endogenous calcium levels, selectively cleaved the $145,000 \mathrm{Da}(145 \mathrm{kDa})$ neurofilament protein subunit to yield 143 and $140 \mathrm{kDa}$ neurofilament proteins that are also major constituents of the axonal cytoskeleton. This process represents a posttranslational modification of the neurofilament protein subunit rather than the initial step in its degradation (Nixon et al., 1982, 1983). A second calcium-activated neutral proteinase activity, CANP A, appeared only when calcium levels in the incubating medium were $100 \mu \mathrm{M}$ or higher. CANP A degraded most proteins in RGC axons but acted considerably more rapidly on high-molecular-weight species. In particular, a 290-320 kDa protein in the Group IV (SCb) phase of axoplasmic transport was degraded $3 \times$ faster than other major axonal proteins, including neurofilament proteins and fodrin. When maximally expressed, CANP A activity represented an enormous proteolytic potential in RGC axons-more than $50 \%$ of the total axonal content of proteins larger than $60 \mathrm{kDa}$ could be hydrolyzed within 5 min. The calcium requirements, inhibitor profile, and substrate specificity of CANP A were similar to those of mCANP, the major CANP of mouse brain purified to homogeneity, suggesting that these enzymes may be the same or highly related proteins. The existence in a single neuron type of two CANP activities with markedly different substrate specificities and enzymatic properties emphasizes the possible functional diversity of calcium-activated neutral proteinases in neurons. These functions include the posttranslational modification, as well as degradation of neuronal proteins.

Neutral proteinases that are activated by calcium (calcium-activated neutral proteinase-CANP, or calpain) are believed to have important roles in neural function (Lasek and Hoffman, 1976; Lynch and Baudry, 1984; Nixon, 1983; Zimmerman and Schlaepfer, 1984). Interest in these enzymes stems not only from their high activity in nervous tissue (Banik et al., 1983; Gilbert et al., 1975; Guroff, 1964; Malik et al., 1983; Zimmerman and Schlaepfer, 1984), but also from the multiplicity of their molecular forms (Malik et al., 1983; Zimmerman and Schlaepfer, 1984) and the high affinity of certain CANPs for specific en-

\footnotetext{
Received Nov. 8, 1984; revised Sept. 18, 1985; accepted Sept. 23, 1985.

We are grateful to Jeffrey Minkovitz for preparing the human brain CANP inhibitor and to Kimberly Bishop Logvinenko, Edward Nichols, and William Hamilton for excellent technical assistance. This work was supported by NIH Grants NS15494, NS17535, and the Anna and Seymour Gitenstein Foundation. R.A.N. was a fellow of the Alfred P. Sloan Foundation.

Correspondence should be addressed to Dr. Nixon, Ralph Lowell Laboratories, McLean Hospital, 115 Mill Street, Belmont, MA 02178.

Copyright (C) 1986 Society for Neuroscience $0270-6474 / 86 / 051252-12 \$ 02.00 / 0$
}

dogenous substrates (Lynch and Baudry, 1984; Nixon, 1983; Pant and Gainer, 1980). Brain CANPs active at micromolar calcium concentrations, for example, selectively cleave a protein associated with the glutamate receptor in rat brain (Baudry et al., 1981) and specifically modify the $145 \mathrm{kDa}$ neurofilament protein (NFP) subunit in mouse retinal ganglion cell neurons (Nixon et al., 1983). The latter posttranslational modification occurs in vivo during axoplasmic transport (Nixon et al., 1982). The hypothesis that proteinases, including CANPs, participate in the turnover of neurofilament proteins in vivo has also received experimental support (Roots, 1983; Schlaepfer et al., 1985).

A deeper understanding of these possible neurobiological roles requires strategies for meaningfully analyzing the interactions between CANPs and their endogenous substrates in nervous tissue. Various factors, however, have hindered the development of this methodology. For example, endogenous specific inhibitors of CANP (Murachi, 1983; Vitto and Nixon, 1983) may render the enzyme inactive or minimally active in tissue homogenates. Therefore, once cellular integrity is disrupted, CANP activity measurements may reflect nonphysiological interactions between the enzyme and these inhibitors or other activity-modifying substances. Similarly, the significance of CANP actions on specific proteins in cell-free extracts may be misinterpreted if the proteinase is exposed to substrates that normally reside in separate cellular or subcellular compartments in vivo. During purification and assay, the structures and properties of CANPs may also be readily altered by autolysis (Zimmerman and Schlaepfer, 1982). Finally, the ubiquity of CANPs in vertebrate and invertebrate tissues (Ishiura, 1981; Kishimoto et al., 1981; Murachi, 1983) suggests that a form of the enzyme is likely to be present in all neurons and glia. Since proteolytic responses may vary in different neural cell types (Nixon, 1982), shifts in proteinase activity may be especially difficult to interpret when measured in cell-free preparations from tissues exhibiting cellular heterogeneity.

To reduce the influence of these confounding variables, we have employed cell biological approaches as an adjunct to conventional studies of purified brain proteinases (Nixon, 1982, 1983; Nixon et al., 1983). Axonally transported proteins in RGC axons within the optic nerve and tract of the mouse are selectively radiolabeled in vivo by administering ${ }^{3} \mathrm{H}$-labeled amino acids intravitreally. The specific degradation of these neuronal proteins by axonal proteinases may then be measured by incubating the excised, intact optic pathways in vitro under conditions that preserve tissue integrity. By maintaining the normal topographical relationships between the proteinases and their normal endogenous substrates in a single neuron cell type, the proteolytic events observed are more likely to reflect in vivo processes.

In the present study, CANP activities were selectively mea- 
sured in retinal ganglion cell axons and compared with the major CANP activity purified from mouse brain. We describe here certain properties of axonal CANPs, including their potential activity and specificity for endogenous neuronal proteins. In the accompanying paper (Nixon, 1986), we compared the relative activity of CANPs in axons and in optic glia in situ. Together, these studies provide new evidence for multiple CANP activities in neurons, preferential localization of some forms of the enzyme in neurons or neuronal processes, and high affinity of CANPs for certain neuronal proteins.

\section{Materials and Methods}

In all experiments, we employed 2- and 3-month-old male or female C57BL/6J mice (Jackson Laboratories, Bar Harbor, ME) bred in this laboratory and maintained on a $12 \mathrm{hr}$ light-dark cycle. Primary optic pathways of mice killed by cervical dislocation were dissected as previously described (Nixon et al., 1983). The dissected specimen, measuring $9 \mathrm{~mm}$ in length, consisted of the optic nerve severed at the scleral surface of the eye, the optic chiasm, and a length of optic tract extending to, but not including, terminals in the lateral geniculate nucleus. In experiments involving radiolabeled proteins, anesthetized mice were injected intravitreally with $15-50 \mu \mathrm{Ci}$ of $\mathrm{L}-2,3-{ }^{3} \mathrm{H}$-proline (specific activity, 3-50 Ci/mmol, New England Nuclear, Cambridge, MA) using a glass micropipette apparatus (Nixon, 1980).

\section{Electron microscopy}

Optic pathways subjected to various in vitro incubations were fixed at room temperature by immersion in $1.5 \%(\mathrm{vol} / \mathrm{vol})$ paraformaldehyde and $1 \%$ glutaraldehyde in $0.1 \mathrm{~m}$ sodium phosphate buffer $(\mathrm{pH} 7.3)$. Some mice were anesthetized with ether and perfused through the heart with the same fixative. After postfixation with $1 \%$ osmium tetroxide in 0.1

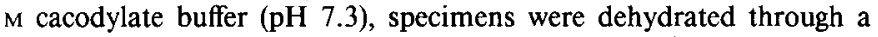
graded series of alcohols, infiltrated with propylene oxide, and embedded in Poly-Bed 812. One-micron sections were stained with toluidine blue. Ultrathin sections were stained with $1 \%$ (vol/vol) aqueous uranyl acetate and $1 \%$ lead citrate and examined in a Jeol EM.

\section{Analysis of proteolysis in situ in retinal ganglion cell axons}

Optic pathways freshly dissected from mice sacrificed $6 \mathrm{~d}$ after the intravitreal injection of ${ }^{3} \mathrm{H}$-proline were incubated under varying conditions in HEPES medium ( $25 \mathrm{~mm}$ HEPES, $6 \mathrm{~mm} \mathrm{KCl}, 110 \mathrm{~mm} \mathrm{NaCl}$, $5.6 \mathrm{~mm}$ glucose adjusted to $\mathrm{pH} 7.4$ with $\mathrm{NaOH})$ containing cycloheximide $(9.5 \mathrm{~mm})$ and chloramphenicol $(0.3 \mathrm{mg} / \mathrm{ml})$ to inhibit the reutilization in glial cells of ${ }^{3} \mathrm{H}$-proline released from axonal proteins by proteolysis (Nixon, 1980). Optic pathways were preincubated at $0^{\circ} \mathrm{C}$ for $20 \mathrm{~min}$ in $0.75 \mathrm{ml}$ of HEPES medium containing the indicated inhibitors or activators and then incubated at $37^{\circ} \mathrm{C}$ in fresh medium for varying lengths of time. In order to establish that agents in the medium could adequately penetrate the intra-axonal space in fresh tissues, additional experiments were carried out on optic pathways that had undergone two cycles of rapid freezing on dry ice and brief thawing before incubation. The effects of the tested substances on CANP in fresh and frozenthawed specimens were similar.

The exceedingly rapid action of CANP B on the $145 \mathrm{kDa}$ neurofilament protein subunit necessitated modification of this method to study the effects of enzyme inhibitors. In addition to the tested inhibitor, 50 mM EGTA was added to the preincubation medium to inhibit CANP activity. To ensure rapid entry of EGTA and inhibitors into the axons, the optic pathways were frozen and thawed once prior to analysis. Following preincubation $\left(15 \mathrm{~min}\right.$ at $0^{\circ} \mathrm{C}$ and $15 \mathrm{~min}$ at $\left.37^{\circ} \mathrm{C}\right)$, CANP B was reactivated by replacing the medium with one lacking EGTA but containing $4 \mathrm{mM} \mathrm{CaCl}_{2}$ as well as the tested inhibitor. Loss of the $145 \mathrm{kDa}$ neurofilament protein and generation of 143 and $140 \mathrm{kDa}$ forms occurred at a constant logarithmic rate for at least $10 \mathrm{~min}$. During this time, CANPs requiring near millimolar calcium concentrations (CANP A) were not appreciably activated. Incubated tissues and the incubating medium were stored at $-70^{\circ} \mathrm{C}$ for up to 1 week before SDS-PAGE and quantitative analyses of radiolabeled proteins.

One-dimensional SDS-PAGE of unincubated and incubated tissues was performed by the procedure of Laemmli (1970) on $20 \mathrm{~cm}$ slab gels using $4-7 \%$ or $5-15 \%$ linear polyacrylamide gradients (Nixon et al., 1983). Proteins were identified on gels by comparison to molecularweight standards or cytoskeletal proteins prepared from mouse brain by axonal flotation (Brown et al., 1981). Replicate $5 \mu$ l aliquots were taken before electrophoresis to determine the radioactivity added to each gel lane. The total radioactivity in each optic pathway before incubation (dpm) was calculated as the sum of the radioactivity loaded onto the gel, residual radioactivity in the homogenizer (usually $5-10 \%$ of the radioactivity loaded), and radioactivity in the incubation medi$\mathrm{um}$. The radioactivity released into the incubation medium during incubations was associated with amino acids and small peptides (Nixon, 1980, and unpublished observations). After electrophoresis, the radioactivity in selected proteins, corrected for the residual protein radioactivity in the homogenizer, was expressed as a percentage of the total radioactivity in the optic pathway before incubation and is referred to as the "fractional dpm" (Nixon et al., 1983). The total radioactivity in a given protein varied less than $3 \%$ when measured in identical samples from a single homogenate of optic pathway. The fractional $\mathrm{dpm}$ for each protein was independent of the ${ }^{3} \mathrm{H}$-proline dose $(5-50 \mu \mathrm{Ci})$ and, in different optic pathways, varied less than $7 \%$ from experiment to experiment. The extent of proteolysis, reflecting relative CANP activity, is represented by the expression

$$
X=1-(a / b)
$$

where $a$ equals the fractional $\mathrm{dpm}$ after incubation and $b$ equals the fractional dpm before incubation.

\section{Purification of CANP from mouse brain}

Whole brains were dissected free of meninges and surface vasculature and frozen in liquid nitrogen within $1 \mathrm{~min}$ after mice were killed by cervical dislocation. Twenty grams of tissue were homogenized in $4 \mathrm{vol}$ of cold $0.05 \mathrm{M}$ Tris $\mathrm{HCl}$, pH 7.4, containing $5 \mathrm{~mm}$ dithiothreitol (DTT) and $5 \mathrm{~mm}$ EDTA. All subsequent steps were carried out at $0-4^{\circ} \mathrm{C}$. After centrifugation at $30,000 \times g$, the supernatant was applied to a $2.0 \times 30$ $\mathrm{cm}$ column of DEAE-cellulose (Whatman DE-52) equilibrated with $0.05 \mathrm{~m}$ Tris, $\mathrm{pH} 7.4$, containing $5 \mathrm{~mm}$ DTT and $5 \mathrm{~mm}$ EDTA. All subsequent steps employed buffers containing $2 \mathrm{mM}$ DTT and $1 \mathrm{~mm}$ EDTA. After extensive washing, the column was eluted with a $1500 \mathrm{ml}$

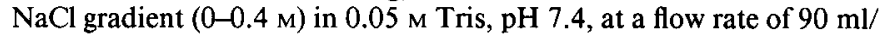
$\mathrm{hr}$. The fractions containing the major peak of CANP activity toward ${ }^{14} \mathrm{C}$-azocasein (see below) were pooled and the approximately $250 \mathrm{ml}$ volume was applied directly to a $1.5 \times 50 \mathrm{~cm}$ column of phenyl-Sepharose (Pharmacia) previously equilibrated with $0.05 \mathrm{M}$ Tris, $\mathrm{pH} 7.4$, buffer containing $0.3 \mathrm{M} \mathrm{NaCl}$. After applying the DE- 52 pool, the column was washed with three column volumes of the equilibration buffer. CANP activity was then eluted with $0.05 \mathrm{M}$ Tris- $\mathrm{HCl}, \mathrm{pH} 7.4$, buffcr. Fractions containing CANP activity were concentrated on an Amicon pressure diafiltration unit fitted with a PM-10 filter and applied to a $2.5 \times 120$ $\mathrm{cm}$ column of Ultrogel AcA 44 previously equilibrated with $0.05 \mathrm{M}$ Tris- $\mathrm{HCl}$ buffer, $\mathrm{pH}$ 7.4. The column was developed in the same buffer at $20 \mathrm{ml} / \mathrm{hr}$ to yield a single peak of activity with a $K_{\mathrm{av}}$ of approximately 0.179 . The fractions with enzyme activity were pooled and applied to a $1.0 \times 20 \mathrm{~cm}$ column of DEAE Bio-gel A (Bio Rad) equilibrated with $0.05 \mathrm{M}$ Tris- $\mathrm{HCl}, \mathrm{pH} 7.4$, containing $2 \mathrm{~mm}$ DTT and $1 \mathrm{~mm}$ EDTA. The CANP activity was eluted at $30 \mathrm{ml} / \mathrm{hr}$ with a $0-0.4 \mathrm{M} \mathrm{NaCl}$ gradient $(500 \mathrm{ml})$. Activity was pooled and dialyzed against $0.05 \mathrm{M} \mathrm{Tris}-\mathrm{HCl}$, pH 7.4, with $2 \mathrm{~mm}$ DTT and $1 \mathrm{~mm}$ EDTA, and then stored frozen at $-70^{\circ} \mathrm{C}$ in $10 \%$ glycerol.

\section{Assay of purified mouse brain CANP}

${ }^{14} \mathrm{C}$-azocasein substrate was prepared by reductive alkylation with ${ }^{14} \mathrm{C}$ formaldehyde (specific activity, $47 \mathrm{mCi} / \mathrm{mmol}$; New England Nuclear, Cambridge, MA) (Dottavio-Martin and Ravel, 1978). To $100 \mu \mathrm{l}$ of enzyme solution was added $100 \mu \mathrm{l}$ of $0.05 \mathrm{M}$ Tris buffer, $\mathrm{pH} 7.4$, containing $2 \mathrm{~mm}$ DTT, $20 \mathrm{mg} / \mathrm{ml}$ of ${ }^{14} \mathrm{C}$-azocasein (about $10,000 \mathrm{dpm}$ ) and $10 \mathrm{~mm}$ calcium chloride. After $20 \mathrm{~min}$ at $30^{\circ} \mathrm{C}$, the reaction was terminated with $100 \mu \mathrm{l}$ of $5 \mathrm{mg} / \mathrm{ml}$ azocasein and $300 \mu \mathrm{l}$ of $10 \%$ trichloroacetic acid. Enzyme activity was measured as the radioactivity in the acid-soluble fraction after centrifugation. Acid-soluble radioactivity was determined in samples lacking enzyme, and this value was subtracted from experimental samples as nonenzymatic "background." The activity increased linearly with the time of incubation or with the amount of enzyme protein added. Studies of the relationship between calcium concentration and enzyme activity were carried out in calcium-EGTA buffers prepared by varying the concentration of total calcium in a solution containing $0.67 \mathrm{~mm}$ EGTA, $10 \mathrm{~mm}$ HEPES ( $\mathrm{pH}$ 7.4), and 10 $\mathrm{mM} \mathrm{NaCl}$. Free calcium levels were determined using a calcium ion electrode (Corning Glass). 
Purification of endogenous CANP inhibitor and analysis of effects on CANPS

Endogenous CANP inhibitor with a molecular weight of $50 \mathrm{kDA}$ was purified to homogeneity from postmortem human brain (J. Minkovitz and R. A. Nixon, unpublished observations) using the method of Nakamura et al. (1984). A weight of $2 \mu \mathrm{g}$ of inhibitor protein completely inhibited the activity of $1 \mu \mathrm{g}$ of purified mouse brain CANP.

The effects of the inhibitor on CANP A and CANP B were measured in optic pathway homogenates. Although tissue homogenization substantially diminished both enzyme activities and eliminated the cell specificity of the measurements, the residual activity of each enzyme was sufficient to quantitate the effects of the endogenous CANP inhibitor. For studies of CANP A, homogenates of radiolabeled optic pathways in HEPES medium containing $2 \mathrm{~mm}$ DTT were preincubated for $15 \mathrm{~min}$ at $0^{\circ} \mathrm{C}$ with or without CANP inhibitor (5 $\mu \mathrm{g}$ protein). Equal aliquots of each were then incubated for $60 \mathrm{~min}$ at $32^{\circ} \mathrm{C}$ in the presence of $4 \mathrm{mM} \mathrm{CaCl}_{2}$. $\mathrm{An}$ additional aliquot of homogenate lacking inhibitor was incubated with $5 \mathrm{~mm}$ EGTA. After incubation, the calcium-dependent loss of the radiolabeled 140-145 kDa neurofilament protein complex was measured as described above. The procedure for studies of CANP B included the following modifications. Leupeptin $(100 \mu \mathrm{g} / \mathrm{ml})$ was added to the HEPES medium during each incubation to inhibit CANP activity. CANP B activity was measured as the progressive decrease in the ratio of radiolabeled $145 \mathrm{kDa}$ neurofilament protein subunits to 143 and $140 \mathrm{kDa}$ forms (Nixon et al., 1983).

\section{Degradation of cytoskeletal proteins by $m C A N P$}

Cytoskeletal protein fractions were prepared by the method of Chiu and Norton (1982) from optic pathways dissected from mice $6 \mathrm{~d}$ after intravitreal injection with ${ }^{3} \mathrm{H}$-proline $(20-25 \mu \mathrm{Ci})$. Aliquots of the radiolabeled cytoskeletal protein fraction were incubated with concentrations of mouse brain mCANP chosen to yield about $50 \%$ degradation of the 140-145 kDa NFP complex during a $30 \mathrm{~min}$ incubation. Incubating buffers and conditions were the same as those described above for brain mCANP. Reactions were terminated by adding PAGE sample buffer containing $10 \mathrm{~mm}$ EDTA. Mixtures were subjected to SDS-PAGE, and the radioactivity in individual proteins was quantitated as described above. Incubations of cytoskeletal proteins in the absence of mCANP resulted in no detectable protein degradation.

\section{Results}

Electron microscopic analysis of mouse optic pathways incubated in vitro

Optic pathways exhibited essentially normal ultrastructure during incubation under the in vitro conditions employed to measure CANP activity. The small diameter of the mouse optic nerve $(0.26-0.33 \mathrm{~mm})$ obviated the need to scction the tissue in order to provide adequate gas exchange between the tissue and medium (Dunlop et al., 1975; Nixon, 1980). After freshly dissected optic pathways were incubated for $2 \mathrm{hr}$ at $37^{\circ} \mathrm{C}$ in HEPES medium containing $4 \mathrm{mM} \mathrm{CaCl}_{2}$, the fine structure of axoplasm was largcly preserved. In transverse sections of optic nerve (Fig. $1 B$ ), neurofilaments, appearing as multiple punctate profiles, and microtubules, as $25 \mathrm{~nm}$ circular profiles, retained their normal spatial orientation and were present in the same relative proportions as in RGC axons from mice following fixation by intracardiac perfusion (Fig. 1A) or from unincubated optic pathways fixed by direct immersion (not shown). The vast majority of axons still appeared normal after $4 \mathrm{hr}$ of incubation (Fig. 1C), although, in a few axons, separation of the axolemma from the internal oligodendroglial membrane and increased vacuolation of the axoplasm occurred (Fig. 1D). Longitudinal sections of optic axons from pathways incubated for $1.5 \mathrm{hr}$ with $4 \mathrm{mM} \mathrm{CaCl}_{2}$ (Fig. 2, $B$ and $C$ ) displayed a reticulated lattice of neurofilaments and microtubules characteristic of the normal axoplasmic matrix (Fig. $2 A$ ). Axonal regions, such as the node of Ranvier, which are known to be particularly sensitive to toxins and ischemia, displayed well-preserved axoplasmic structure (Fig. 2C). When intra-axonal calcium levels were elevated further by including calcium ionophore $A 23187$ as well as $4 \mathrm{mM}$ calcium in the incubation medium, axonal changes became prominent and consisted of a progressive loss of neurofilaments (Fig. 2D) and eventual replacement of all axonal cytoskeletal elements by loose aggregates of flocculent dense material after $2 \mathrm{hr}$ of incubation (Fig. $2 E$ ). Myelinated axons were affected earlier and more prominently than unmyelinated axons, and changes were far more extensive in axons than in myelin or supporting cells. The structural alterations were largely prevented by EGTA (10 mm) and leupeptin (data not shown). The penetration of exogenous calcium was facilitated even further by quick-freezing and thawing optic pathways before incubation. Except for cold-induced depolymerization of microtubules (Rodriguez-Echandia and Piezzi, 1968; Fig. $2 F$ ), axonal structure was still relatively preserved after short incubations $(<5$ $\min$ ) in the presence of $4 \mathrm{~mm} \mathrm{CaCl}_{2}$. The loosening of myelin lamellae in frozen-thawed pathways facilitated access to the axonal compartment by various test agents in the medium (see below).

\section{Distribution and characterization of radiolabeled axonal proteins}

Proteins in unincubated optic pathways from mice sacrificed 6 $\mathrm{d}$ after intravitreal ${ }^{3} \mathrm{H}$-proline injection were analyzed by SDSPAGE on $20 \mathrm{~cm}$ slab gels. The distribution of radiolabeled proteins in eight consecutive $1.1 \mathrm{~mm}$ segments of the optic pathway is shown in Figure 3. At this postinjection interval, most transported proteins were distributed relatively uniformly along the optic pathways. Most radiolabeled proteins were constituents of the Group IV (SCb) phase of axoplasmic transport (Black and Lasek, 1980; Levine and Willard, 1980) and were conveyed at a velocity of $1-2 \mathrm{~mm} / \mathrm{d}$, based on quantitative analyses at different postinjection intervals (Nixon and Logvinenko, 1986; Nixon et al., 1986). Proteins in the Group V (SCa) phase $(0.5-0.8 \mathrm{~mm} / \mathrm{d})$ consisting of neurofilament proteins, tubulins, and several additional proteins distributed primarily in proximal segments of optic pathway. In all experiments, the entire $9 \mathrm{~mm}$ length of the optic pathway, dissected as described in Materials and Methods, was used for measurements of proteolysis.

\section{Calcium-stimulated proteolysis of proteins in situ within RGC axons}

Optic pathways from mice $6 \mathrm{~d}$ after ${ }^{3} \mathrm{H}$-proline injection were incubated for $1.5 \mathrm{hr}$ at $\mathrm{pH} 7.4$ in HEPES medium containing either no calcium, $4 \mathrm{~mm} \mathrm{CaCl}_{2}$, or $10 \mathrm{~mm}$ EGTA. These samples and additional unincubated control optic pathways were then subjected to SDS-PAGE, and the distribution of radioactivity in 180-200 consecutive $1 \mathrm{~mm}$ slices of each gel lane was determined.

When the incubation medium lacked calcium, loss of radioactivity from major axonal proteins was restricted to the 145 $\mathrm{kDa}$ neurofilament protein, which converted quantitatively to 143 and $140 \mathrm{kDa}$ neurofilament proteins (Fig. 4; Nixon et al., $1982,1983)$. This specific limited proteolytic modification was completely blocked by EGTA and sulfhydryl reagents (e.g., mersalyl, iodoacetate, $N$-ethylmaleimide) and by purified endogenous CANP inhibitor from human brain (Table 1; see Materials and Methods). Endogenous CANP inhibitors from other tissue sources have been shown to inhibit CANPs selectively when tested against various proteinases (Lepley et al., 1985; Nakamura et al., 1984). Although CANP B displayed the calcium and sulfhydryl dependence and sensitivity to endogenous inhibitors that are characteristic of CANPs, its response to certain inhibitors clearly distinguished it from a second axonal CANP activity described below (Table 1). Peptide inhibitors of thiolproteinases, leupeptin, and antipain (not shown) had minimal effect on CANP B activity under conditions that completely inhibited other axonal CANPs. In addition, phenylmethylsul- 

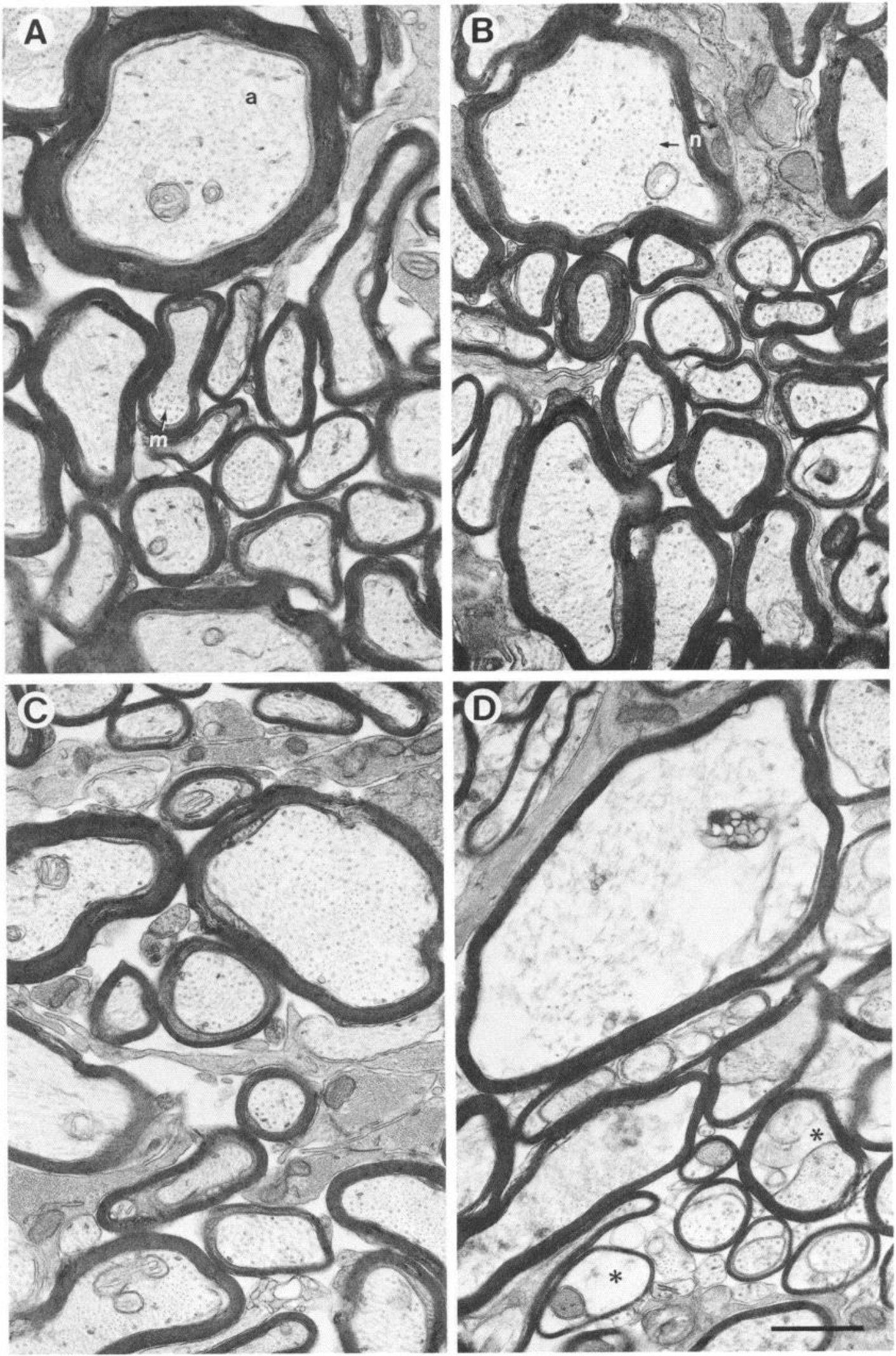

Figure 1. Ultrastructure of retinal ganglion cell axons before and after incubating excised optic nerve segments in vitro in calcium-containing medium. A transverse section of optic nerve from an anesthetized mouse perfused through the heart with $1.5 \%$ paraformaldehyde- $1 \%$ glutaraldehyde $(A)$ is compared with an optic nerve fixed by direct immersion after dissection $(B)$. Axonal ultrastructure is preserved after incubating the optic nerve for $2 \mathrm{hr}$ at $37^{\circ} \mathrm{C}$ in an isotonic HEPES medium (see Materials and Methods) containing $4 \mathrm{~mm}$ calcium $(C)$. Even after $4 \mathrm{hr}$ of incubation $(D)$, most axons exhibit normal ultrastructure, although a few display degenerative changes (asterisks). 

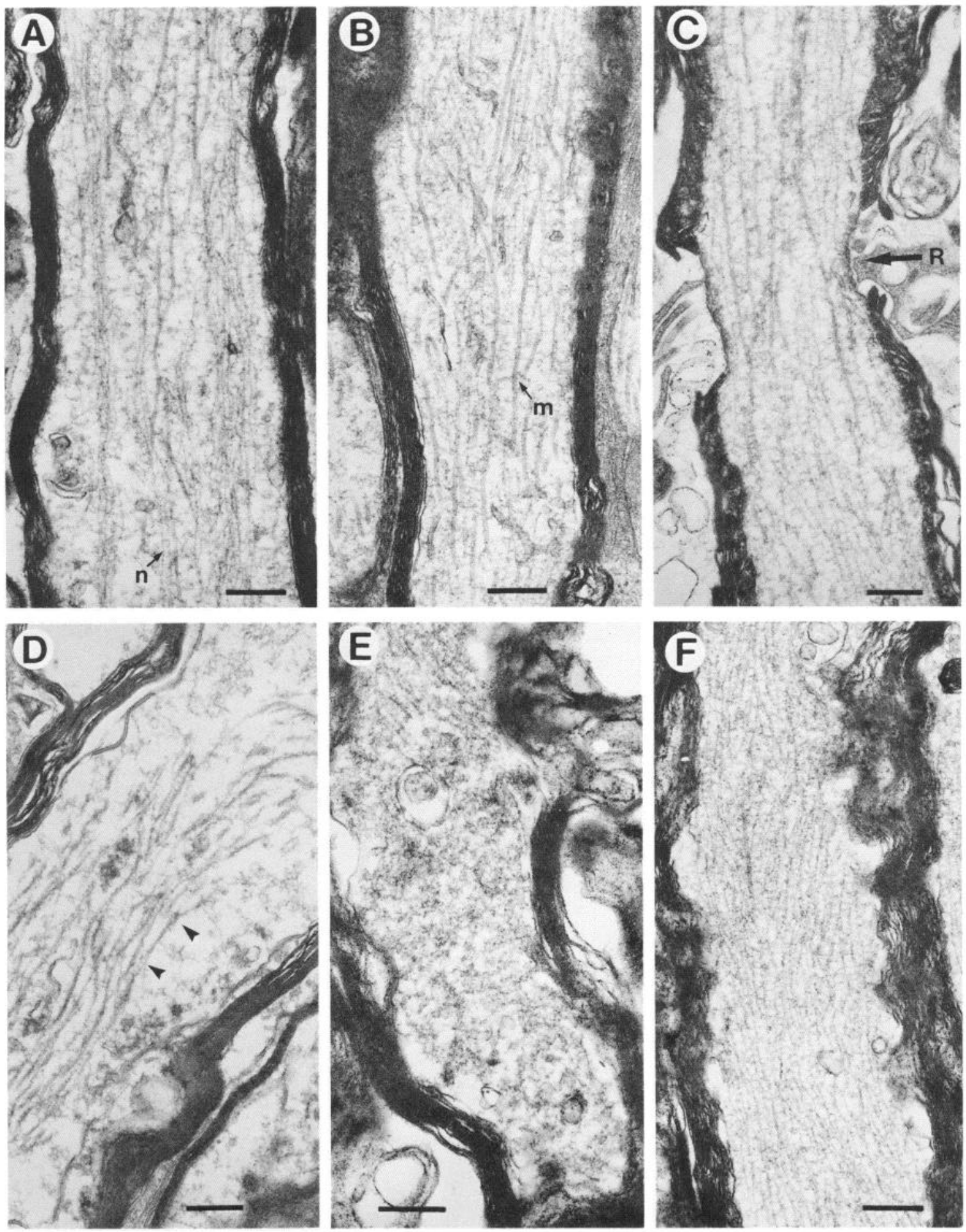

Figure 2. Ultrastructure of retinal ganglion cell axons after in vitro incubation. A longitudinal section of optic nerve from a mouse fixed by intracardiac perfusion $(A)$ is compared with optic nerves fixed by direct immersion after in vitro incubation in an isotonic HEPES medium (see Materials and Methods) under the following conditions: $4 \mathrm{~mm}$ calcium, $1.5 \mathrm{hr}, 37^{\circ} \mathrm{C}(B, C) ; 4 \mathrm{~mm}$ calcium and calcium ionophore A23187,10 $\mu \mathrm{g} /$ $\mathrm{ml}, 1 \mathrm{hr}, 37^{\circ} \mathrm{C}(D) ; 4 \mathrm{~mm}$ calcium and calcium ionophore $\mathrm{A} 23187,10 \mu \mathrm{g} / \mathrm{ml}, 2.5 \mathrm{hr}, 37^{\circ} \mathrm{C}(E)$. $F$, The effect of quick-freezing and thawing the optic nerve twice prior to incubating the tissue in HEPES medium with $4 \mathrm{~mm}$ calcium for $5 \mathrm{~min}$ at $37^{\circ} \mathrm{C}$. Examples of neurofilaments $(n$ in $A)$ and microtubules ( $m$ in $B$, arrows in $D$ ) are indicated. A node of Ranvier $(R)$ is displayed in $C$.

fonyl fluoride (PMSF) inhibited CANP B activity by more than $50 \%(p<0.001$; Student's $t$ test) but had little effect on other axonal and brain CANPs (Table 1).

The addition of millimolar concentrations of calcium to the incubating medium markedly stimulated axonal proteolysis. Af- ter the incubations, radioactivity was decreased in many axonal proteins, particularly those of high molecular weight. Proteins in the Group IV and Group V transport phases were well represented among the degraded species. The loss of radioactivity from endogenous proteins after incubating with calcium con- 
stituted $2.75 \pm 0.65 \%(n=4)$ of the total radioactivity in optic pathways before incubation. In other studies, optic pathways before and after incubation with $4 \mathrm{mM} \mathrm{CaCl}_{2}$ were homogenized in $10 \%$ trichloroacetic acid and centrifuged to recover the acidsoluble radioactivity (Nixon, 1980). Calcium-stimulated proteolysis released a similar percentage of the total radioactivity in the optic pathway $(2.84 \pm 0.15 \%, n=12)$ into the acid-soluble fraction during a $90-\mathrm{min}$ incubation, indicating that the axonal proteins that disappeared during incubation with calcium were hydrolyzed to small polypeptides or free amino acids.

CANP activity toward susceptible proteins in axons was maximal at neutral $\mathrm{pH}$, although the optimal $\mathrm{pH}$ range was broad (6.5-8.5, data not shown). The broad $\mathrm{pH}$ optimum possibly reflected the integrity of $\mathrm{pH}$ buffering mechanisms in the excised pathway, since axonal calcium-stimulated proteolytic activity in tissues quick-frozen before incubation exhibited a narrower $\mathrm{pH}$ optimum with a peak at $\mathrm{pH} 7.4$ and less than $50 \%$ activity below pH 6.0 or above $\mathrm{pH} 9.0$.

To examine certain properties of axonal CANP activity quantitatively, the $140-145 \mathrm{kDa}$ neurofilament protein complex (containing the 145,143 , and $140 \mathrm{kDa}$ species) and a protein with a molecular weight on denaturing gels of approximately $300 \mathrm{kDa}$, "300 kDa protein" (Figs. 3-5), were selected as "reference" substrates. Preliminary experiments indicated that both proteins were highly susceptible to CANP, and neither was released undegraded into the medium during incubation. In addition to being highly labeled after intravitreal injection, each protein was easily identified and well separated from other proteins after one-dimensional SDS-PAGE (Fig. 3). No major radiolabeled proteins of corresponding size were observed in glial cells (Nixon, 1986). Since each is among the major radiolabeled polypeptides of highest molecular weight on gels, it was unlikely that significant amounts of comigrating proteolytic fragments would be generated from larger radioactive proteins during incubation. Finally, the $140-145$ kDa NFP complex and the 300 $\mathrm{kDa}$ protein are representatives of different axoplasmic transport phases-Group V (Nixon et al., 1982) and Group IV, respectively. The activity of axonal CANPs toward these proteins was compared under varying in vitro conditions with the activity of mCANP-a millimolar calcium-requiring CANP purified from mouse brain-toward ${ }^{14} \mathrm{C}$-azocasein.

\section{mCANP from mouse brain}

The $30,000 \times g$ supernatant of mouse brain contained more than $95 \%$ of the detectable CANP activity but also contained one or more specific CANP inhibitors (Vitto and Nixon, 1983). mCANP eluted from a DE-52 column at $0.2 \mathrm{M} \mathrm{NaCl}$, free of endogenous CANP inhibitor. The enzyme peak presented over $80 \%$ of the total CANP activity at 50 -fold increased specific activity (Table 2). mCANP was further purified by hydrophobic affinity chromatography on phenyl-Sepharose, gel-filtration chromatography on Ultrogel AcA 44, and a second ion-exchange chromatography on DEAE Bio-Gel (Table 2). The purified enzyme, enriched a total of 3550 -fold, exhibited a molecular weight of $95-100 \mathrm{kDa}$ by gel filtration on Sephacryl 300 (data not shown). SDS-PAGE revealed that the enzyme was composed of 78 and $27 \mathrm{kDa}$ subunits (Fig. 6).

\section{Effect of inhibitors on axonal CANP A activity and brain $M C A N P$}

Axonal CANP A activity was inhibited completely by EGTA $(10 \mathrm{mM})$, endogenous CANP inhibitor from human brain, and sulfhydryl reagents, including $5 \mathrm{~mm}$ mersalyl, $5 \mathrm{~mm} N$-ethylmaleimide, and $2 \mathrm{~mm}$ iodoacetate (Table 1). Leupeptin, a peptide inhibitor of some thiol proteinases, also completely abolished CANP A activity. TLCK was partially inhibitory in fresh and frozen tissue. By contrast, PMSF had little, if any, inhibitory

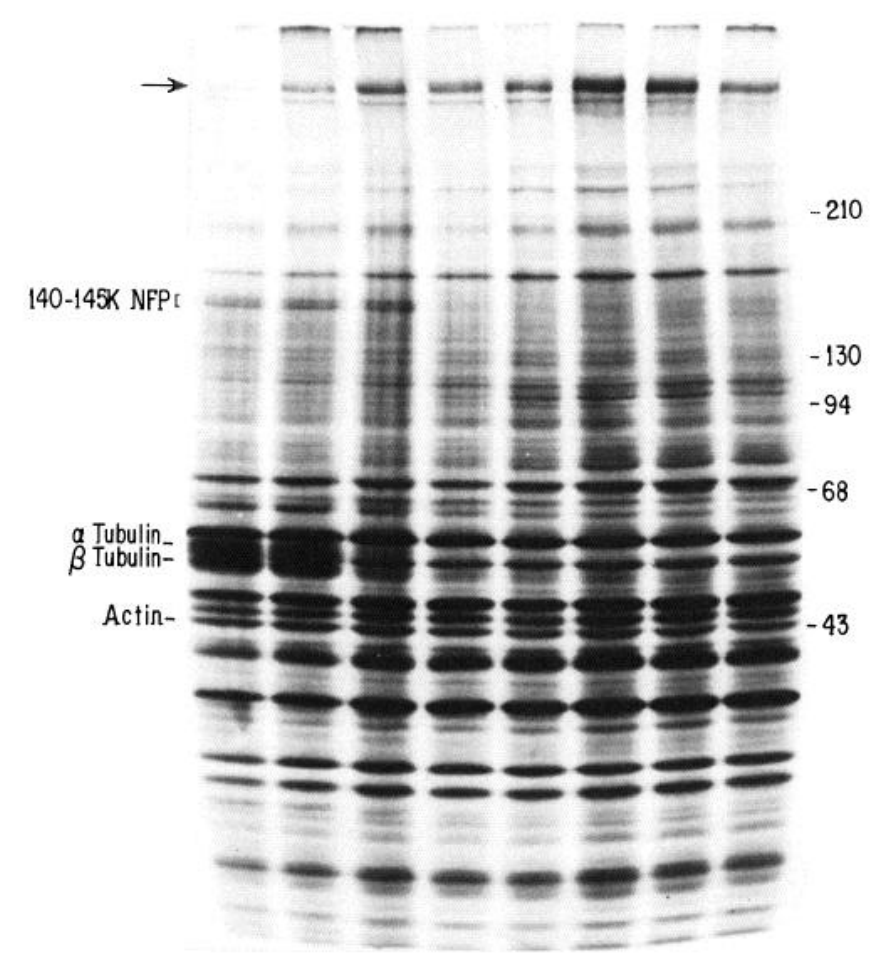

Figure 3. Distribution of radiolabeled proteins along retinal ganglion cell axons from mice $6 \mathrm{~d}$ after intravitreal injection of ${ }^{3} \mathrm{H}$-proline. Eight consecutive $1.1 \mathrm{~mm}$ segments of the optic pathway extending from the proximal optic nerve to the middle of the optic tract were subjected to SDS-PAGE, and radiolabeled proteins were revealed by fluorography (see Materials and Methods). Molecular weights of standard reference proteins are given at right. The middle-sized neurofilament protein subunit ("145K NFP"), $\alpha$ - and $\beta$-tubulin subunits, and a protein (arrow) with an apparent molecular weight of about $300,000 \mathrm{Da}$ (or $300 \mathrm{kDa}$ protein), which is employed as a substrate for CANP in later experiments, are indicated at left. This segmental analysis of the optic pathway illustrates the axonal distribution of proteins in Group IV (SCb) of axoplasmic transport, typified by the $300 \mathrm{kDa}$ protein, and Group V (SCa) proteins, typified by tubulin and $145 \mathrm{kDa}$ NFP. The entire $9 \mathrm{~mm}$ length of the optic pathway was employed in all studies.

effect under conditions in which it substantially inhibited CANP B (Table 1).

Brain mCANP exhibited similar responses to enzyme inhibitors (Table 1). Quantitative differences compared to CANP A activity in RGC axons included a slight inhibitory effect at high concentrations of PMSF ( $1 \mathrm{mM}$ ) and more robust inhibition by TLCK $(100 \%$ at $1 \mathrm{~mm})$.

\section{Ion sensitivity of axonal CANP A activity and brain $M C A N P$}

In the absence of added calcium, neither of the two reference axonal proteins was detectably degraded after $90 \mathrm{~min}$ in vitro (Table 3), even though the $145 \mathrm{kDa}$ neurofilament subunit was almost completely converted to the 143 and $140 \mathrm{kDa}$ species by CANP B. Therefore, if these proteins were degraded at endogenous calcium levels, the rate was below the detection limit of the assay $(4 \% / \mathrm{hr})$.

To investigate the rate at which exogenous calcium entered intact optic pathways in vitro, freshly dissected or frozen and thawed specimens were incubated in medium containing varying concentrations of ${ }^{45} \mathrm{Ca}$. In both tissue preparations, calcium levels reached $75-80 \%$ of the maximal level after $5 \mathrm{~min}$ and were maximal by $10 \mathrm{~min}$ (results not shown). Although intraaxonal free calcium levels could not be determined by this method, 


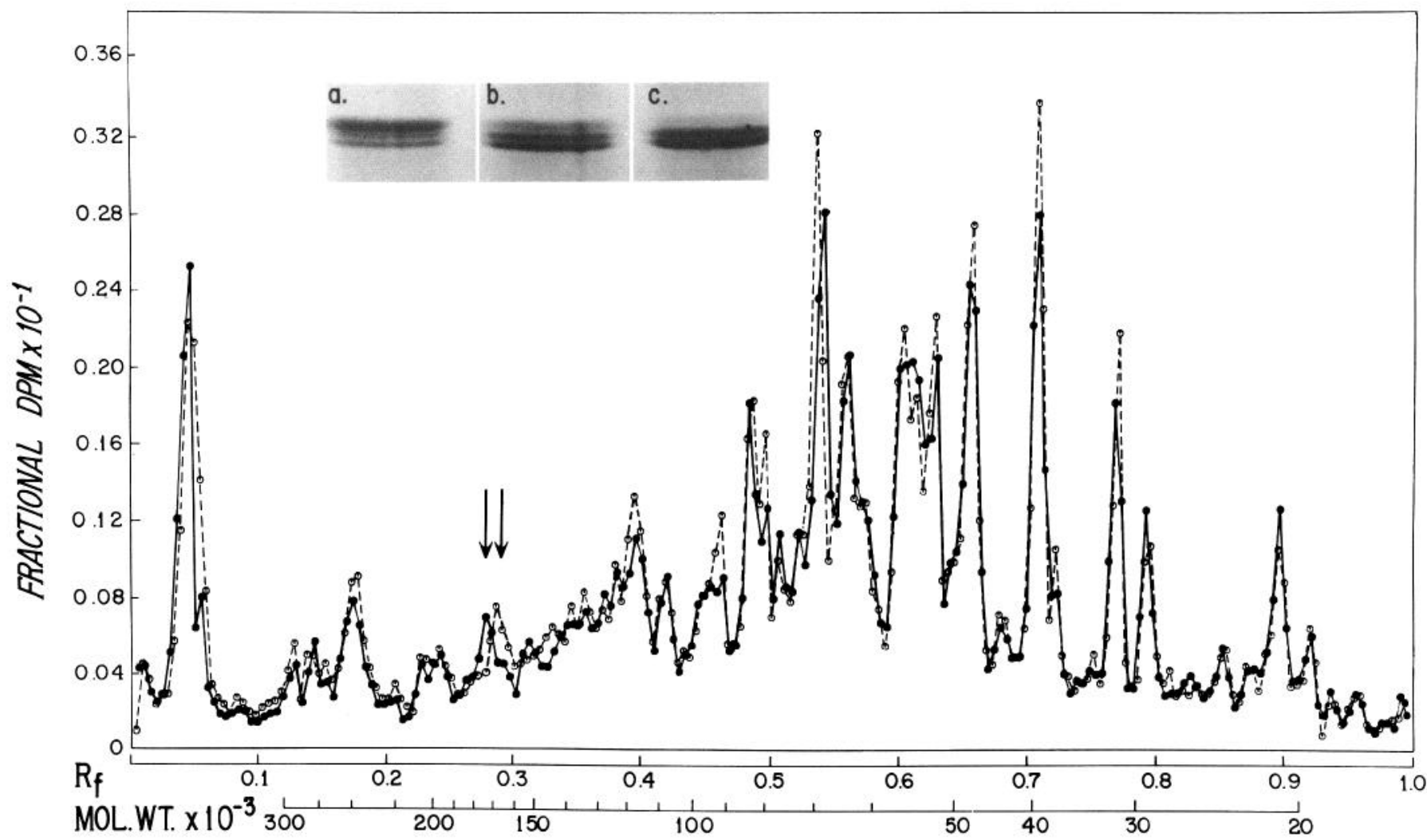

Figure 4. Specificity of axonal CANP toward axonally transported proteins at endogenous calcium concentrations. Freshly dissected optic pathways were incubated for $1.5 \mathrm{hr}$ at $37^{\circ} \mathrm{C}$ in HEPES medium containing no additions, i.e., no exogenous calcium (--O--) or containing $10 \mathrm{~mm}$ EGTA $(-)$ to chelate endogenous free calcium. After SDS-PAGE, radioactivity in consecutive $1 \mathrm{~mm}$ slices of each gel lane was determined and expressed as a percentage of the total protein radioactivity (fractional dpm). The total radioactivity associated with proteins of a typical gel was $200,000-$ $500,000 \mathrm{dpm}$. The graph illustrates that calcium-dependent changes in the electrophoretic patterns of radiolabeled axonal proteins are limited to one region of the gel. This change, which involves a shift in molecular size of proteins in the $140-145 \mathrm{kDa}$ region, is further illustrated by the corresponding Coomassie blue-stained gel (inset). This gel shows a progressive loss of the $145 \mathrm{kDa}$ NFP and generation of 143 and $140 \mathrm{kDa}$ NFPs during incubation at $37^{\circ} \mathrm{C}$ in HEPES medium for intervals of $0(a), 0.5(b)$, and $1 \mathrm{hr}(c)$ (see Materials and Methods). A difference in the two electrophoretic patterns at $R_{f}=0.46$ is a gel-slicing artifact.

Table 1. Effects of inhibitors on the activities of axonal CANPs and purified brain mCANP

\begin{tabular}{|c|c|c|c|c|c|}
\hline \multirow[b]{5}{*}{ Inhibitor } & \multicolumn{5}{|c|}{$\%$ Inhibition } \\
\hline & \multirow{4}{*}{$\begin{array}{l}\begin{array}{l}\text { Axonal } \\
\text { CANP B }\end{array} \\
145 \mathrm{kDa} \\
\text { NFP }^{a}\end{array}$} & \multirow{2}{*}{\multicolumn{2}{|c|}{ Axonal CANP A }} & \multirow{2}{*}{\multicolumn{2}{|c|}{$\frac{\text { Brain mCANP }}{{ }^{14} \mathrm{C} \text {-azocasein }}$}} \\
\hline & & & & & \\
\hline & & \multirow[b]{2}{*}{$\begin{array}{l}300 \mathrm{kDa} \\
\text { protein }\end{array}$} & \multirow{2}{*}{$\begin{array}{l}140-145 \\
\mathrm{kDa} \\
\mathrm{NFP} \\
\text { complex }^{a}\end{array}$} & \multirow{2}{*}{$\begin{array}{l}\text { Inhib- } \\
\text { itor } \\
\text { at } 0.1 \\
\mathrm{mM}\end{array}$} & \multirow{2}{*}{$\begin{array}{l}\text { Inhib- } \\
\text { itor } \\
\text { at } 1.0 \\
\mathrm{mM}\end{array}$} \\
\hline & & & & & \\
\hline EGTA (10 mм) & 100 & 100 & 100 & 100 & 100 \\
\hline Mersalyl (5 mM) & 100 & 58 & 100 & 100 & 97 \\
\hline Iodoacetic acid (2 mM) & 91 & 100 & 100 & 54 & 100 \\
\hline Human brain CANP inhibitor $(50 \mu \mathrm{g} / \mathrm{ml})$ & 100 & 100 & 100 & $100^{b}$ & \\
\hline Leupeptin $(100 \mu \mathrm{g} / \mathrm{ml})$ & 12 & 100 & 95 & 92 & 97 \\
\hline TLCK (1 mM) & 0 & 42 & 36 & 91 & 100 \\
\hline PMSF (1 mм) & 50 & 10 & 5 & 3 & 22 \\
\hline
\end{tabular}

The activities of purified mCANP and of CANP A and CANP B in RGC axons were measured without added inhibito as described in Materials and Methods. Other samples were preincubated with the indicated inhibitor for $15 \mathrm{~min}$ before measuring proteolytic activity. Percent of inhibition was calculated from the expression $1-a / b$, where $a$ and $b$ represent activity in the presence and absence of inhibitor, respectively. Each value is the average of three to five determinations. SEM was less than $10 \%$

- CANP B activity was determined from the loss of the $145 \mathrm{kDa}$ NFP subunit, which converts to 143 and $140 \mathrm{kDa}$ species. No loss of radioactivity in the total $140-145 \mathrm{kDa}$ NFP complex $(145,143$, and $140 \mathrm{kDa}$ NFPs) is observed under the conditions of assay. Calcium-dependent loss of radioactivity from the 140-145 kDa NFP complex occurs only from the action of CANP A.

${ }^{b}$ Inhibitor concentration $(50 \mu \mathrm{g} / \mathrm{ml})$. 


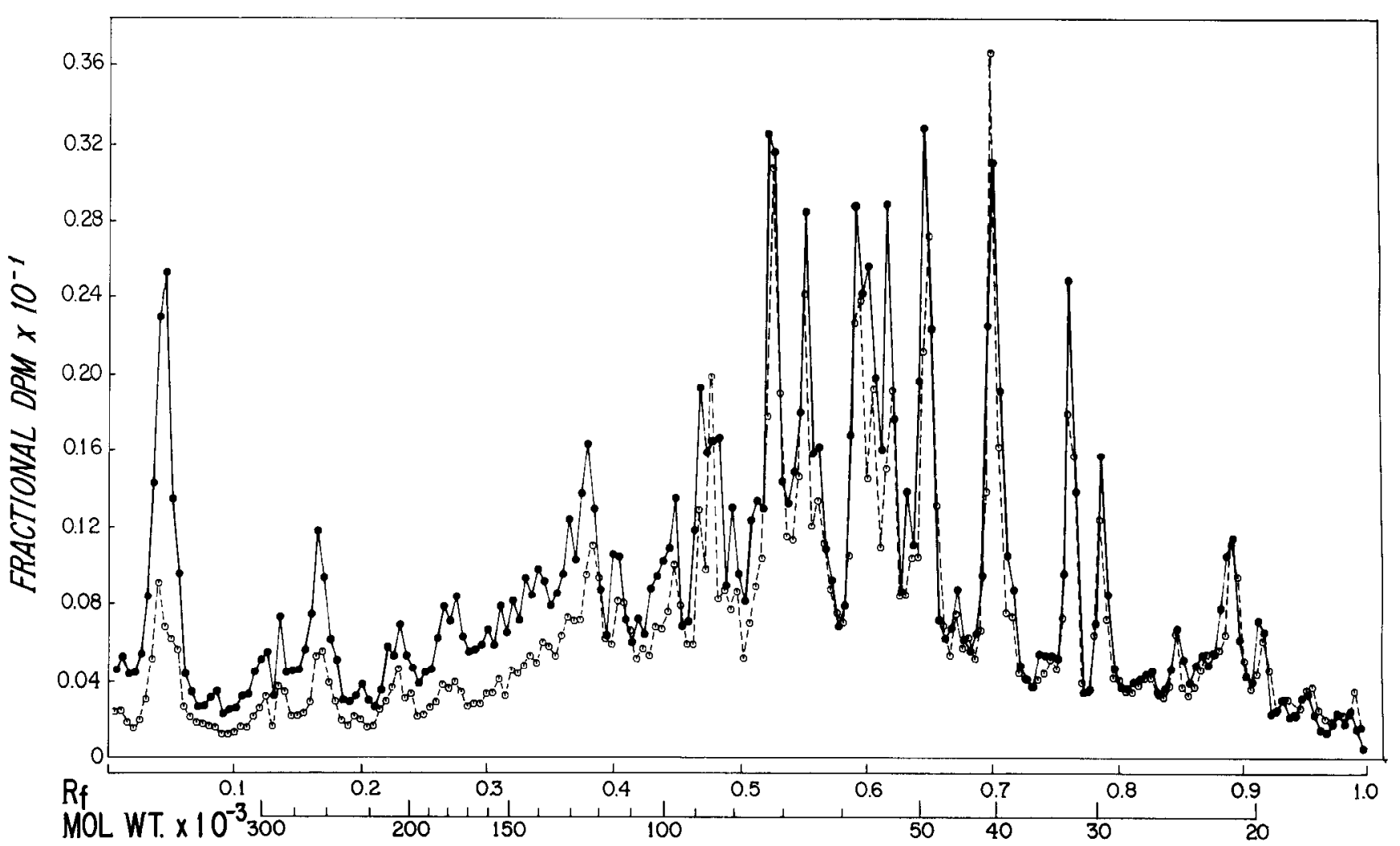

Figure 5. Specificity of axonal CANPs toward axonally transported proteins at high calcium concentrations. Electrophoretic patterns of radiolabeled Group IV and Group V proteins in RGC axons are compared (see Fig. 4) after freshly dissected optic pathways were incubated for $1.5 \mathrm{hr}$ at $37^{\circ} \mathrm{C}$ in HEPES medium containing either $4 \mathrm{~mm} \mathrm{CaCl}_{2}\left(--\mathrm{O}_{--)}\right.$or $10 \mathrm{~mm}$ EGTA (-). CANP activity is reflected in the differences between these two graphs.

the total exogenous calcium concentration in the tissue was proportional to that in the medium between 0.1 and $10 \mathrm{~mm}$.

Proteolysis was detectable when the medium contained 100 $\mu \mathrm{M}$ calcium but was not maximal until calcium concentrations reached $10 \mathrm{~mm}$ (Fig. 7). The $300 \mathrm{kDa}$ protein was susceptible at lower exogenous calcium levels $(100 \mu \mathrm{M})$ than the $140-145$ $\mathrm{kDa}$ neurofilament protein complex (400 $\mu \mathrm{M}$ calcium). Strontium effectively substituted for calcium but only at higher concentration $(>0.4 \mathrm{~mm})$. Other divalent cations had minimal or no effect. To examine whether the lower effectiveness of certain ions was due to poorer penetration into axons, twice-frozen and thawed optic pathways were first preincubated in medium containing $1 \mathrm{~mm}$ EGTA to chelate endogenous calcium and then incubated with the tested ion (at $4 \mathrm{~mm}$ ). Under these conditions, the relative effectiveness of the ions was similar to that observed in fresh tissue (data not shown).

Purified mouse brain mCANP also required millimolar calcium concentrations for maximal activation (Fig. 7). When assayed by measuring the release of acid-soluble fragments from ${ }^{14} \mathrm{C}$-azocasein, enzyme activity was first detected at $500 \mu \mathrm{M}$ $\mathrm{CaCl}_{2}$. If, however, we used an assay analogous to the measurement of axonal CANPs, namely, the loss of radiolabeled 140-145 kDa neurofilament protein complex from gels, activity was detected at $100 \mu \mathrm{M}$ calcium. Purified mouse brain mCANP showed the same relative sensitivity to other divalent ions as axonal CANP A (Table 3).

Under all conditions, axonal CANP A degraded the $300 \mathrm{kDa}$ protein more rapidly than the $140-145 \mathrm{kDa}$ neurofilament protein complex (Figs. 8 and 9) and other major radiolabeled proteins in axons (data not shown). Rates for each reference protein were logarithmic and constant until the proteins were nearly completely eliminated. In freshly dissected optic pathways in- cubated with $4 \mathrm{~mm}$ calcium, $300 \mathrm{kDa}$ protein was degraded $300 \%$ more rapidly than the neurofilament protein $\left(t_{1 / 2}=95 \mathrm{vs}\right.$ $290 \mathrm{~min}$; Fig. 8). At maximal CANP A activation, $300 \mathrm{kDa}$ protein degradation was twice as rapid $\left(t_{1 / 2}=2.5 \mathrm{vs} 4.5 \mathrm{~min}\right.$; Fig. 9).

\section{Discussion}

Excised central or peripheral nerves retain their normal ultrastructure for many hours in vitro in physiological media lacking calcium (Brady et al., 1980; Nixon, 1983; Schlaepfer, 1983). Physiological processes such as respiration (Gerard, 1927; Majno and Karnovsky, 1958) and fast axoplasmic transport (Alpert et al., 1980; Frizell et al., 1975) also continue in transected fiber tracts for similar periods of time. These observations provide a rationale for investigating mechanisms of proteolysis in intact mouse optic pathways in vitro, where proteolytic activity can be maximally preserved and experimentally manipulated while largely maintaining the normal intracellular milieu, including topographical relationships between axonal proteinases, endogenous substrates, and potential regulatory factors. In the present experiments, the fine structure of RGC axons and satellite cells in excised mouse optic pathways remained relatively intact for at least several hours in vitro even when proteolysis was stimulated by adding calcium to the incubating medium. Since axonal proteins were selectively radiolabeled in these morphologically intact preparations, alterations in the amounts of individual radioactive proteins during the in vitro incubation reflect actions of the enzymes residing specifically in axons (Nixon, 1982; Nixon et al., 1985b).

Although a cell biological approach is well suited to studying many aspects of proteolysis, including cellular localization, substrate specificity and cell-specific shifts of activity, its potential 


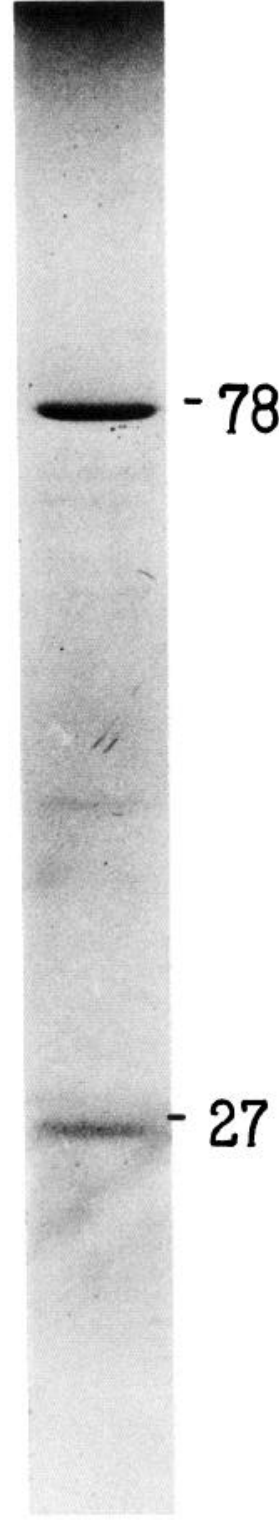

Figure 6. mCANP of mouse brain. The major millimolar-calciumrequiring form of CANP was purified from whole mouse brain as summarized in Table 2 (also see Materials and Methods). The native enzyme, a $95-100 \mathrm{kDa}$ protein by gel-filtration chromatography, is composed of two subunits exhibiting molecular weights of 78 and $27 \mathrm{kDa}$ by SDS-PAGE ( $9 \%$ acrylamide).

limitations for defining some features of proteinases should also be considered (Nixon, 1980, 1983). For example, although altering the ion composition of the medium and using enzyme inhibitors enables the activity of specific proteinases to be selectively expressed within intact axons, the precise effects of such manipulations on the intracellular environment may be difficult to determine. Also, since many metabolic processes are preserved in intact axons in vitro, any alteration of the medium may influence proteolysis indirectly through intermediate metabolic steps. Further definition of some enzymatic properties, therefore, requires correlative studies on the purified enzyme and substrate(s), provided that the limitations of this approach are also appreciated (Nixon, 1983).

Our results indicate that at least two CANPs are present in a single neuron cell-type. The behavior of these enzymes toward endogenous substrates suggests that they serve quite different

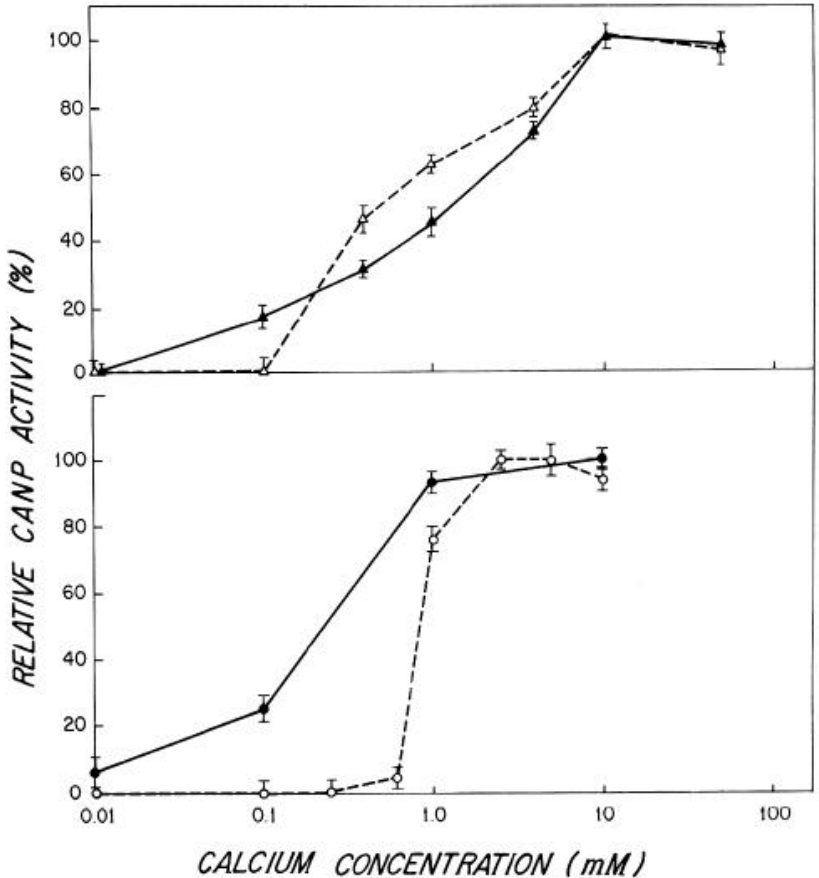

Figure 7. Calcium dependence of axonal CANP and purified mouse brain mCANP activity toward different protein substrates. Upper panel, Optic pathways from mice injected intravitreally with ${ }^{3} \mathrm{H}$-proline were incubated for $1.5 \mathrm{hr}$ at $37^{\circ} \mathrm{C}$ in an isotonic HEPES medium containing the indicated calcium concentrations buffered with appropriate amounts of EGTA (see Materials and Methods). The activity of axonal CANPs toward the $140-145 \mathrm{kDa}(--\Delta--)$ and $300 \mathrm{kDa}$ protein $(-\Delta-)$ was determined after SDS-PAGE, as described in Materials and Methods. Lower panel, The relative activity of purified mouse brain CANP toward the 140-145 kDa NFP complex in enriched cytoskeletal protein fractions ( $4 \mathrm{mg}$ protein $/ \mathrm{ml} ;--O--)$ and toward ${ }^{14} \mathrm{C}$-azocasein $(4 \mathrm{mg} / \mathrm{ml}$; - -) measured as described in Materials and Methods. Each point is the mean value and SEM (error bar) for 3-4 determinations.

roles in neurons. Proteolysis expressed optimally at near millimolar calcium levels in RGC axons (CANP A) appears to reflect the activity of the major calcium-activated neutral proteinase in brain (mCANP) or a closely related enzyme. The calcium requirements and enzymatic properties of mCANP purified from mouse brain resemble those of mCANPs isolated from neural (Malik et al., 1983; Vitto and Nixon, 1983; Zimmerman and Schlaepfer, 1982) and non-neural (Ishiura, 1981; Murachi, 1983; Nixon, 1983) tissues of various species. At least $95 \%$ of the calcium-dependent proteolytic activity measured in RGC axons required near-millimolar calcium concentrations and showed the same response to divalent ions and enzyme inhibitors as brain mCANP. We have also recently observed that brain mCANP and axonal CANP A display similar specificities for neuronal proteins (R. A. Nixon and D. Perlo, unpublished observations). When proteins were cleaved by CANP A in intact axons, the proteolytic fragments were rapidly hydrolyzed to small polypeptides and amino acids. The latter process may involve additional endo- and exopeptidases present in RGC axons (Nixon, 1983; Nixon and Froimowitz, 1982), since purified mCANP generates primarily large polypeptide fragments from proteins (Zimmerman and Schlaepfer, 1982). These observations, therefore, suggest that, when fully activated, CANP A initiates a sequence of events in neurons leading to the complete degradation of proteins.

In contrast, the CANP activity detected at endogenous calcium levels (CANP B) was limited to the quantitative conversion of the $145 \mathrm{kDa}$ neurofilament protein subunit to 143 and 
Table 2. Purification of calcium-activated neutral proteinase from mouse brain

\begin{tabular}{lccccc} 
& $\begin{array}{l}\text { Total protein } \\
(\mathrm{mg})\end{array}$ & $\begin{array}{l}\text { Total } \\
\text { activity } \\
\text { (units) }\end{array}$ & $\begin{array}{l}\text { Specific } \\
\text { activity } \\
\text { (units/mg) }\end{array}$ & $\begin{array}{l}\text { Yield } \\
\text { (\%) }\end{array}$ & $\begin{array}{l}\text { Purifi- } \\
\text { cation } \\
\text { (-fold) }\end{array}$ \\
\hline $30,000 \times g$ supernatant & 2381 & 60,821 & 25.5 & - & - \\
DE-52 cellulose & 101 & 110,536 & 1094 & 100 & 42.9 \\
Phenyl-Sepharose & 10.5 & 87,544 & 8337 & 79.2 & 327 \\
Ultrogel AcA-44 & 1.62 & 37,693 & 23,267 & 34.1 & 912 \\
DEAE-Biogel & 0.221 & 20,007 & 90,530 & 18.1 & 3550 \\
\hline
\end{tabular}

A typical purification of mCANP from $100 \mathrm{gm}$ of whole mouse brain. One unit of activity is equal to the hydrolysis of $1 \mu \mathrm{g}$ alzocasein $/ \mathrm{hr}$.

$140 \mathrm{kDa}$ neurofilament proteins (Nixon et al., 1983). The physiological relevance of this process is suggested by the fact that an identical event occurs during axoplasmic transport in vivo (Nixon et al., 1982). The action of CANP B, unlike that of CANP $A$, reflects posttranslational modification rather than degradation of the $145 \mathrm{kDa}$ neurofilament protein since the resulting products are major cytoskeletal constituents that are not further hydrolyzed after they are generated. Evidence supporting the conclusion that this modification process is a proteolytic event includes the lower molecular weight and minimal change in isoelectric point of the products and inhibition of the process by the serine proteinase inhibitor PMSF or by a specific inhibitor of CANP from human brain. Although the $145 \mathrm{kDa}$ neurofilament protein is highly phosphorylated (Julien and Mushynski, 1982; Wong et al., 1984), removal of phosphate groups with alkaline phosphatase yielded forms different from ones generated by CANP B (S. E. Lewis and R. A. Nixon, unpublished observations). CANP B resembles other CANPs with respect to its calcium and thiol dependence and sensitivity to endogenous CANP inhibitors, although it is distinguishable from CANP A on the basis of its restricted substrate specificity, lower calcium requirement, relative insensitivity to leupeptin, and inhibition by PMSF.

CANP B activity in vivo and in vitro is greatest in distal regions

Table 3. Ion sensitivities of axonal CANP and brain mCANP activities

\begin{tabular}{|c|c|c|c|c|c|}
\hline \multirow[b]{2}{*}{$\begin{array}{l}\text { Medium additions } \\
\text { (mM) }\end{array}$} & \multicolumn{2}{|c|}{$300 \mathrm{kDa}$ protein } & \multicolumn{2}{|c|}{$\begin{array}{l}140-145 \mathrm{kDa} \text { NFP } \\
\text { complex }\end{array}$} & \multirow{2}{*}{$\begin{array}{l}\text { Brain } \\
\text { mCANP } \\
\text { relative } \\
\text { degra- } \\
\text { dation } \\
\text { rate }\end{array}$} \\
\hline & $\begin{array}{l}\text { \% Total } \\
\text { dpm }^{a}\end{array}$ & $\begin{array}{l}\text { Relative } \\
\text { degra- } \\
\text { dation } \\
\text { rate }\end{array}$ & $\begin{array}{l}\text { \% Total } \\
\mathrm{dpm}^{a}\end{array}$ & $\begin{array}{l}\text { Relative } \\
\text { degra- } \\
\text { dation } \\
\text { rate }\end{array}$ & \\
\hline No incubation & $4.25 \pm 0.18$ & 0 & $3.49 \pm 0.12$ & 0 & 0 \\
\hline \multicolumn{6}{|l|}{$\mathrm{Ca}^{2+}:$} \\
\hline 0 & $4.30 \pm 0.14$ & 0 & $3.65 \pm 0.14$ & 0 & 0 \\
\hline 1 & $2.99 \pm 0.18$ & 79 & $2.97 \pm 0.13$ & 62 & 78 \\
\hline 4 & $2.23 \pm 0.19$ & 100 & $2.83 \pm 0.11$ & 100 & 100 \\
\hline 50 & $1.57 \pm 0.19$ & 133 & $2.69 \pm 0.16$ & 121 & 65 \\
\hline + Ionophore $\mathrm{A} 23187+4 \mathrm{~mm} \mathrm{Ca}^{2+}$ & $1.71 \pm 0.12$ & 126 & $2.67 \pm 0.09$ & 124 & \\
\hline+ Ionophore A23187 + $50 \mathrm{mM} \mathrm{Ca}^{2+}$ & $1.95 \pm 0.12$ & 114 & $2.62 \pm 0.06$ & 132 & \\
\hline \multicolumn{6}{|l|}{$\mathrm{Sr}^{2+}:$} \\
\hline 0.4 & $4.23 \pm 0.12$ & 0 & $3.72 \pm 0.24$ & 0 & \\
\hline 1.0 & $3.14 \pm 0.16$ & 55 & $3.11 \pm 0.12$ & 58 & 39 \\
\hline 4.0 & $2.29 \pm 0.11$ & 97 & $2.84 \pm 0.10$ & 98 & 110 \\
\hline \multicolumn{6}{|l|}{$\mathrm{Ba}^{2+}:$} \\
\hline 1 & $3.90 \pm 0.18$ & 17 & $3.62 \pm 0.23$ & 0 & 0 \\
\hline 4 & $3.52 \pm 0.09$ & 36 & $3.23 \pm 0.12$ & 39 & 61 \\
\hline \multicolumn{6}{|l|}{$\mathrm{Mn}^{2+}$} \\
\hline 4 & $4.15 \pm 0.09$ & 5 & $3.56 \pm 0.14$ & 0 & 0 \\
\hline \multicolumn{6}{|l|}{$\mathbf{M g}^{2+}$} \\
\hline 4 & $4.29 \pm 0.16$ & 0 & $3.51 \pm 0.13$ & 0 & 0 \\
\hline
\end{tabular}

Intact optic pathways were incubated at $37^{\circ} \mathrm{C}$ for $1.5 \mathrm{hr}$ in isotonic HEPES medium (see Materials and Methods) containing the indicated additional agents. Incubations with purified mouse brain CANP were carried out as described in Materials and Methods. Relative degradation rate refers to activity expressed relative to activity measured in the presence of $4 \mathrm{mM}$ calcium. Each value is the mean \pm SEM for three to eight separate determinations.

a These values indicate the radioactivity in the isolated protein substrate after tissue incubation expressed as a percentage of the total radioactivity in the optic pathway before incubation ("fractional percentage" as defined in Materials and Methods). 


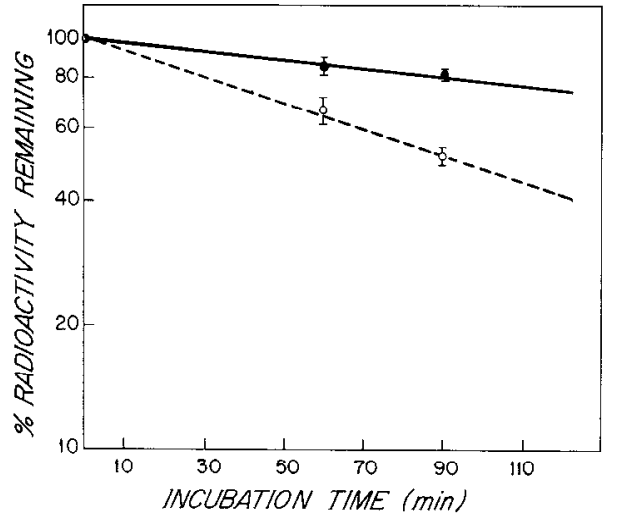

Figure 8. Relative degradation rates of the 140-145 kDa NFP complex and the $300 \mathrm{kDa}$ protein by CANPs in RGC axons. The figure depicts the rate of disappearance of neurofilament protein $(--)$ or $300 \mathrm{kDa}$ protein $(--\mathrm{O}--)$ when freshly dissected radiolabeled optic pathways were incubated at $37^{\circ} \mathrm{C}$ for varying intervals in HEPES medium containing $4 \mathrm{~mm}$ calcium as described in Materials and Methods. Each point is the mean value and SEM (error bar) for four determinations.

of RGC axons (Nixon et al., 1982, 1983). In the same axonal regions, phosphorylation of certain sites on NFPs (Nixon et al., 1985a) and deposition of neurofilaments into a stationary cytoskeletal lattice (Nixon and Logvinenko, 1986; Nixon et al., $1985 \mathrm{~b}$ ) are more active compared to proximal axonal regions. These observations therefore raise the possibility that these posttranslational processes may be interrelated and that CANP B may be involved in shaping the three-dimensional geometry of the neurofilament network in axons.

The physiological role of CANPs such as CANP A, which exhibit broad substrate specificity and calcium requirements in the millimolar range, remains unclear. The existence of highmolecular-weight CANPs with micromolar calcium sensitivity and their ability to convert to millimolar calcium-sensitive forms have suggested that mCANP may be generated during purification (Zimmerman and Schlaepfer, 1984). In this regard, however, CANP A activity is high in intact RGC axons of rapidly dissected optic pathways and proceeds at a constant rate during incubation intervals of 5-90 min (Nixon, 1980). Thus, if CANP $A$ is generated artifactually, its formation from a precursor micromolar calcium-sensitive CANP would have to reach completion within minutes after optic pathways are exposed to calcium. On the other hand, if CANP A is normally present in axons, several observations support a direct or indirect role in physiological proteolysis. Since mCANP may be modified by autolysis (Dayton, 1982; Suzuki et al., 1981) to generate forms with micromolar calcium sensitivities, mCANP could represent a proenzyme that yields physiologically active molecules under appropriate conditions. Alternatively, the high calcium concentrations needed to activate mCANP or CANP A maximally do not necessarily exclude physiological activity of unmodified CANP A. The level of proteolysis required for the in vivo turnover of some proteins may be quite modest. A half-life of 10 $\mathrm{d}$, for example, implies a degradation rate of only $0.3 \% / \mathrm{hr}$. Less than $0.1 \%$ of the potential CANP activity in RGC axons might, therefore, support the physiological turnover of a protein with susceptibility equal to that of a neurofilament protein. The calcium requirement for $\mathrm{mCANP}$ activities in this range has not yet been investigated.

A $300 \mathrm{kDa}$ protein was degraded much more rapidly than other proteins known to be highly susceptible to CANPs, including neurofilament proteins (Gilbert et al., 1975; Pant and Gainer, 1980; Zimmerman and Schlaepfer, 1982) and fodrin (Lynch and Baudry, 1984; Nixon, 1985). Unlike other major

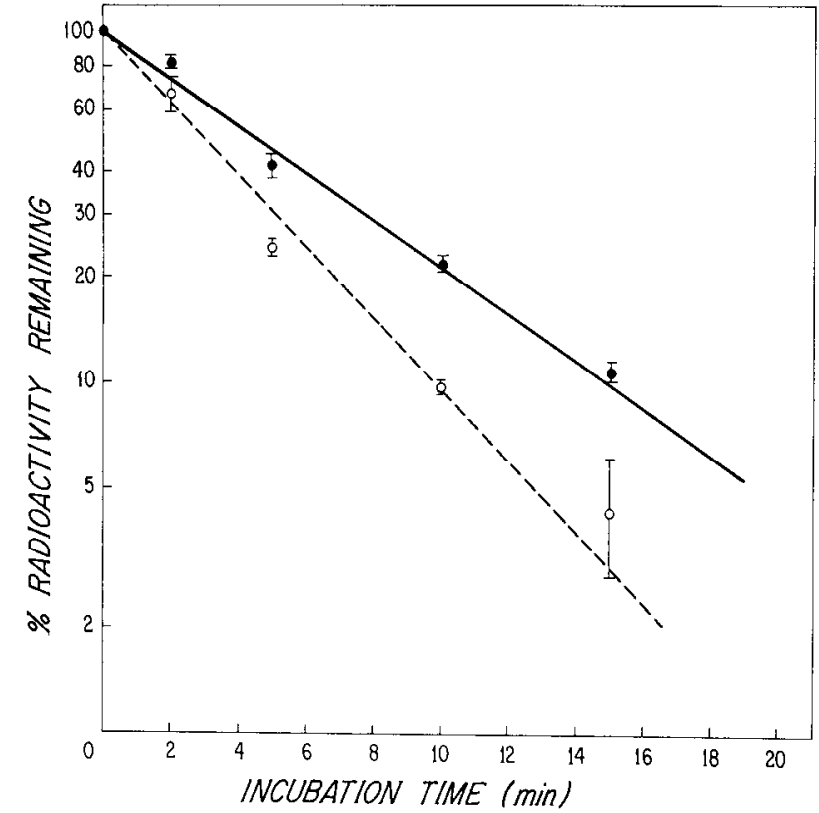

Figure 9. Relative degradation rates of 140-145 kDa NFP complex and the $300 \mathrm{kDa}$ protein by CANPs in RGC axons. This figure shows the rate of disappearance of these proteins in optic pathways that were frozen and thawed before incubation at $37^{\circ} \mathrm{C}$ in HEPES medium containing $4 \mathrm{~mm}$ calcium to maximally stimulate CANP A activity. Symbols as in Figure 8.

slowly transported proteins, this protein exhibits an exceptionally high ratio of newly synthesized molecules to total molecules (cstimated by Coomassie blue dye-binding), a characteristic that usually implies rapid in vivo turnover. Preliminary observations also suggest that the level of radioactivity associated with this protein after intravitreal injection of radiolabeled amino acids decreases during axoplasmic transport along axons (Nixon, unpublished observations). The apparent affinity of CANP A for $300 \mathrm{kDa}$ protein could therefore indicate a role in the axonal processing of this protein in vivo.

\section{References}

Alpert, R. M., B. Grafstein, and D. L. Edwards (1980) Slow axonal transport in goldfish optic axons. Soc. Neurosci. Symp. 6:83.

Banik, N. L., E. L. Hogan, M. G. Jenkins, J. K. McDonald, W. W. McAlhaney, and M. B. Sostek (1983) Purification of a calciumactivated neutral proteinase from bovine brain. Neurochem. Res. 8 . $1389-1405$.

Baudry, M., M. E. Bundman, E. K. Smith, and G. S. Lynch (1981) Micromolar calcium stimulates proteolysis and glutamate binding in rat brain synaptic membranes. Science 212: 937-938.

Black, M. M., and R. J. Lasek (1980) Slow components of axonal transport: Two cytoskeletal networks. J. Cell Biol. 86: 616-623.

Brady, S. C., S. D. Crothers, C. Nosal, and W. O. McClure (1980) Fast axonal transport in the presence of high $\mathrm{Ca}^{2+}$ : Evidence that microtubules are not required. Proc. Natl. Acad. Sci. USA 77: 5909-5913.

Brown, B. A., R. A. Nixon, P. Strocchi, and C. A. Marotta (1981) Characterization and comparison of neurofilament proteins from rat and mouse C.NS. J. Neurochem. 36:143-153.

Chiu, F.-C., and W. T. Norton (1982) Bulk preparation of CNS cytoskeleton and the separation of individual neurofilament proteins by gel filtration: Dyc-binding characteristics and amino acid compositions. J. Neurochem. 39: 1252-1260.

Dayton, W. R. (1982) Comparison of low-and high-calcium-requiring forms of the calcium-activated protease with their autocatalytic breakdown products. Biochim. Biophys. Acta 709: 166-172.

Dottavio-Martin, D., and J. M. Ravel (1978) Radiolabeling of proteins by reductive alkylation with $\left[{ }^{14} \mathrm{C}\right]$ formaldehyde and sodium cyanoborohydride. Anal. Biochem. 87: 562-565. 
Dunlop, D. S., W. Van Elden, and A. Lajtha (1975) Optimal conditions for protein synthesis in incubated slices of rat brain. Brain Res. 99 . 303-318.

Frizell, M., W. G. McLean, and J. Sjøstrand (1975) Slow axonal transport of proteins: Blockade by interruption of contact between cell body and axon. Brain Res. 86: 67-73.

Gerard, R. W. (1927) Studies on nerve metabolism. II. Respiration in oxygen and nitrogen. Am. J. Physiol. 82: 381-402.

Gilbert, D. S., B. J. Newby, and B. H. Anderson (1975) Neurofilament disguise, destruction and discipline. Nature 256: 586-589.

Guroff, G. (1964) A neutral, calcium-activated protease from the soluble fraction of rat brain. J. Biol. Chem. 239: 149-155.

Ishiura, S. (1981) Calcium-dependent proteolysis in living cells. Life Sci. 29: 1079-1087.

Julien, J.-P., and W. E. Mushynski (1982) Multiple phosphorylation sites in mammalian neurofilament polypeptides. J. Biol. Chem. 257: 10467-10470.

Kishimoto, A., N. Kajikawa, H. Tabuchi, M. Shiota, and Y. Nishizuka (1981) Calcium-dependent neutral proteases, widespread occurrence of a species of protease active at lower concentrations of calcium. J. Biochem. 90: 889-892.

Laemmli, U. K. (1970) Cleavage of structural proteins during the assembly of the head of bacteriophage T4. Nature 227: 680-685.

Lasek, R. J. and P. N. Hoffman (1976) The neuronal cytoskeleton, axonal transport, and axonal growth. In Cell Motility, Vol. 3, R. Goldman, T. Pollard, and J. Rosenbaum, eds., pp. 1021-1049, Cold Spring Harbor Laboratory, New York.

Lepley, R. A., M. Pampusch, and W. R. Dayton (1985) Purification of a high-molecular-weight inhibitor of the calcium-activated proteinase. Biochim. Biophys. Acta 828: 95-103.

Levine, J., and M. Willard (1980) The composition and organization of axonally transported proteins in the retinal ganglion cells of the guinea pig. Brain Res. 194: 137-154

Lynch, G., and M. Baudry (1984) The biochemistry of memory: A new and specific hypothesis. Science 224: 1057-1063.

Majno, G., and M. L. Karnovsky (1958) A biochemical and morphological study of myelination and demyelination. J. Exp. Med. 107. $475-496$

Malik, M. N., M. D. Fenko, K. Iqbal, and H. M. Wisniewski (1983) Purification and characterization of two forms of $\mathrm{Ca}^{2+}$-activated neutral protease from calf brain. J. Biol. Chem. 258: 8955-8962.

Murachi, T. (1983) Intracellular $\mathrm{Ca}^{2+}$-protease and its inhibitor protein: Calpain and calpastatin. In Calcium and Cell Function, Vol. 4, W. Y. Cheung, ed., pp. 377-419, Academic, New York.

Nakamura, M., M. Inomata, M. Hayashi, K. Imahori, and S. Kawashima (1984) Purification and characterization of an inhibitor of calcium-activatcd ncutral protease from rabbit skeletal muscle: $\mathrm{Pu}$ rification of 50,000-dalton inhibitor. J. Biochem. 96: 1399-1407.

Nixon, R. A. (1980) Protein degradation in the mouse visual system I. Degradation of axonally transported and retinal proteins. Brain Res. 200: 69-83.

Nixon, R. A. (1982) Increased axonal proteolysis in myelin-deficient mutant mice. Science 215: 999-1001.

Nixon, R. A. (1983) Proteolysis of neurofilaments. In Neurofilaments, C. A. Marotta, ed., pp. 117-154, U. Minnesota P., Minneapolis
Nixon, R. A. (1986) Fodrin degradation by calcium-activated neutral proteinase (CANP) in retinal ganglion cell neurons and optic glia: Preferential localization of CANP activities in neurons. J. Neurosci. 6: 1264-1271.

Nixon, R. A., and M. Froimowitz (1982) Multiple neutral proteinases in retinal ganglion cell neurons. Trans. Am. Soc. Neurochem. 13: 237.

Nixon, R. A., and K. B. Logvinenko (1986) Multiple fates of newly synthesized neurofilament proteins: Evidence for a stationary neurofilament network distributed nonuniformly along axons of retinal ganglion cell neurons. J. Cell. Biol. 102: 647-659.

Nixon, R. A., B. A. Brown, and C. A. Marotta (1982) Posttranslational modification of a neurofilament protein during axoplasmic transport: Implications for regional specialization of CNS axons. J. Cell Biol. 94: $150-158$.

Nixon, R. A., B. A. Brown, and C. A. Marotta (1983) Limited proteolytic modification of a neurofilament protein involves a proteinase activated by endogenous levels of calcium. Brain Res. 275: 384-388.

Nixon, R. A., S. E. Lewis, and C. A. Marotta (1985a) In vivo phosphorylation of neurofilament proteins in retinal ganglion cell (RGC) neurons. J. Neurochem. 44: S60.

Nixon, R. A., K. B. Logvinenko, and W. H. Fisher (1985b) Evidence for a stationary non-uniform network of neurofilaments along retinal ganglion cell axons. Ann. NY Acad. Sci. 455: 797-799.

Pant, H. C., and H. Gainer (1980) Properties of a calcium-activated protease in squid axoplasm which selectively degrades neurofilament proteins. J. Neurobiol. 11: 1-12.

Rodriguez-Echandia, E. L., and R. S. Piezzi (1968) Microtubules in the nerve fibers of the toad Bufa aremarum. Hensel. J. Cell Biol. 39: 491-497.

Roots, B. I. (1983) Neurofilament accumulation induced in synapses by leupeptin. Science 221: 971-972.

Schlaepfer, W. W. (1983) Neurofilaments of mammalian peripheral nerve. In Neurofilaments, C. A. Marotta, ed., pp. 57-85. U. Minnesota P., Minneapolis.

Schlaepfer, W. W., C. Lee, V. M.-Y. Lee, and U.-J. P. Zimmerman (1985) An immunoblot study of neurofilament degradation in situ and during calcium-activated proteolysis. J. Neurochem. 44: 502509.

Suzuki, K., S. Tsuji, S. Ishiura, Y. Kimura, S. Kubota, and K. Imahori (1981) Autolysis of calcium-activated neutral protease of chicken skeletal muscle. J. Biochem. 90: 1787-1793.

Vitto, A., and R. A. Nixon (1983) Purification and characterization of calcium-activated neutral proteases from mouse and post-mortem human brain. Soc. Neurosci. 9: 758 .

Wong, J., S. B. Hutchison, and R. K. H. Liem (1984) An isoelectric variant of the 150,000-dalton neurofilament polypeptide. Evidence that phosphorylation state affects its association with the filament. J. Biol. Chem. 259: 10867-10874.

Zimmerman, U.-J. P., and W. W. Schlaepfer (1982) Characterization of a brain calcium-activated protease that degrades neurofilament proteins. Biochemistry $21: 3977-3983$.

Zimmerman, U.-J. P., and W. W. Schlaepfer (1984) Multiple forms of Ca-activated protease from rat brain and muscle. J. Biol. Chem. 259: $3210-3218$ 